\title{
Kemampuan Menulis Cerita Fantasi dengan Menggunakan Media Gambar pada Siswa Tunagrahita Ringan
}

\author{
Budi Surono ${ }^{1}$

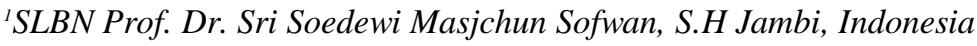 \\ Email: budisurono71@gmail.com
}

INFORMASI ARTIKEL

Terkirim 14-Oktober-2021

Revisi 21-Oktober-2021

Diterima 27-Oktober-2021

Kata kunci:

Menulis, cerita fantasi,

media gambar.

\begin{abstract}
ABSTRAK
Penelitian ini bertujuan untuk mendeskripsikan kemampuan menulis cerita fantasi siswa tunagrahita ringan dengan menggunakan media gambar. Metode dari penelitian ini adalah kuantitaif. Pengumpulan data dilakukan dengan tes, observasi dan dokumentasi. Instrumen yang digunakan dalam penelitian ini berupa tes unjuk kerja. Pemilihan tes ini bertujuan untuk mengukur kemampuan menulis cerita fantasi siswa dengan menggunakan media gambar. Penilaian tes diukur bedasarkan kriteria dan skala penilaian menulis cerita fantasi sesuai dengan yang tercantum pada buku siswa yaitu aspek struktur dan penggunaan bahasa. Hasil penelitian menunjukkan bahwa kemampuan menulis cerita fantasi dengan menggunakan media gambar pada siswa tunagrahita ringan berkategori sangat mampu dengan skor rata-rata 4 yang berada pada interval $4-5,00$ dan memperoleh indeks penilaian 80,6 yang terdapat pada interval skor 70-84 dengan predikat baik. Berdasarkan hasil penelitian, pembelajaran menulis cerita fantasi menjadi lebih baik dengan menggunakan media gambar.
\end{abstract}

\section{Pendahuluan}

Saddhono (2014) mengatakan keterampilan menulis merupakan salah satu bentuk keterampilan berbahasa yang sangat penting, di samping keterampilan menyimak, berbicara, dan membaca, baik selama seseorang mengikuti pendidikan di berbagai jenjang maupun dalam kehidupannya di masyarakat. Menulis ialah menurunkan atau melukiskan lambang-lambang grafik yang menggambarkan suatu bahasa yang dipahami oleh seseorang, sehingga orang-orang lain dapat membaca lambang-lambang grafik itu (Tarigan, 2013). Berdasarkan pernyataan di atas dapat disimpulkan bahwa menulis merupakan sebuah keterampilan berbahasa yang harus dikuasai karena dengan menulis dapat menuangkan pikiran melalui sistem bahasa agar dapat dibaca atau dimengerti orang lain. Mengingat tentang pentingnya peranan menulis, guru harus melatih siswa aktif, kreatif, dan ekspresif. Salah satu pembelajaran menulis yang membutuhkan tingkat kreatif dan penuh ekspresif adalah menulis cerita fantasi.

Cerita fantasi merupakan pengembangan dari teks narasi yang dapat dijadikan sebuah cerita fiktif. Dalam menulis cerita fantasi, siswa mengandalkan daya imajinasinya ketika membayangkan sesuatu yang tidak terjadi di kehidupan nyata. Hal tersebut dapat dilakukan dengan cara memberikan ruang imajinatif dalam pikiran siswa. Cerita fantasi harus menjadi bagian cerita yang diajarkan dan dipraktikkan untuk ditulis anak-anak dalam pembelajaran menulis kreatif karena sebenarnya dunia bermain anak penuh dengan fantasi (Kurniawan, 2014). Di samping itu, menulis cerita fantasi dapat dijadikan salah satu sarana bagi peserta didik dalam menuangkan imajinasi-imajinasi yang berkembang 
di pikiran mereka.

Berdasarkan hasil observasi di lapangan, peneliti menemukan beberapa permasalahan terkait kesulitan siswa dalam pembelajaran menulis cerita fantasi. Permasalahan yang dialami siswa diantaranya yaitu siswa kesulitan dalam menemukan ide, menentukan pilihan kata, mengembangkan alur dan menentukan makna ketika menulis cerita fantasi. Nilai rata-rata kemampuan menulis cerita fantasi siswa pun masih berada dibawah Kriteria Kentutasan Minimal (KKM) yaitu 60. Di samping itu, pemanfaatan media dalam proses pembelajaran masih terbilang kurang. Hal ini berpengaruh kepada hasil belajar siswa yang menunjukkan bahwa kemampuan menulis cerita fantasi siswa berada dibawah KKM yang telah ditetapkan yaitu 70 .

Melihat kondisi demikian, maka perlu adanya alternatif pembelajaran agar siswa tidak lagi mengalami kesulitan dalam menghasilkan sebuah cerita fantasi. Salah satu alternatif yang peneliti usulkan ialah dengan memanfaatkan media pembelajaran berupa media gambar. Media merupakan salah satu komponen terpenting dalam proses belajar mengajar agar tercapainya tujuan pembelajaran. Rimawati (2017) mengatakan bahwa penggunaan media pembelajaran sangat membantu keaktifan siswa dalam proses pembelajaran dan kemudahan bagi guru dalam menyampaikan pesan serta isi materi pembelajaran. Upaya yang dilakukan untuk mencapai keberhasilan belajar peserta didik ialah penggunaan media ajar yang akan mempermudah pemahaman peserta didik terhadap materi yang diajarkan.

Media pembelajaran terbagi menjadi beberapa jenis yaitu media visual, audio visual, komputer, microsoft power point, internet dan multimedia. Media visual dapat memperlancar pemahaman (misalnya melalui elaborasi struktur dan organisasi) dan memperkuat ingatan (Arsyad, 2015). Menurut Brown (2008) pembelajar yang paling berhasil adalah mereka yang memanfaatkan masukan visual maupun auditoris. Pembelajar visual cenderung menyukai gambar, tabel, dan informasi grafis lain. Grafis berfungsi untuk menarik perhatian, memperjelas sajian ide, mengilustrasikan atau menghiasi fakta yang mungkin akan cepat dilupakan (Arsyad, 2015).

Pemilihan objek penelitian di SLBN Prof. Dr. Sri Soedewi MS, S.H Jambi dilakukan dengan beberapa pertimbangan. Alasan pertama karena di SLBN Prof. Dr. Sri Soedewi MS, S.H Jambi media pembelajaran mencukupi akan tetapi pemanfaatannya kurang. Alasan kedua karena nilai hasil pembelajaran cerita fantasi siswa masih dibawah rata-rata. Oleh karena itu, peneliti ingin meneliti Kemampuan Menulis Cerita Fantasi dengan Menggunakan Media Gambar pada Siswa Tunagrahita Ringan

\section{Metode}

Desain penelitian ini menggunakan pendekatan kuantitatif. Hal ini dikarenakan data dari hasil menulis cerita fantasi siswa berupa nilai angka-angka dan dianalisis menggunakan perhitungan statistik. Penelitian ini tergolong kedalam penelitian deskriptif. Penelitian deskriptif dimaksudkan untuk mendeskripsikan suatu situasi atau area populasi tertentu yang bersifat faktual secara sistematis dan akurat. Peneliti mendeskripsikan peristiwa atau kondisi populasi pada saat pembelajaran menulis cerita fantasi dengan menggunakan media gambar.

Penelitian ini bertempat di SLBN Prof. Dr. Sri Soedewi MS, S.H. Waktu penelitian 
dilaksanakan pada bulan Maret semester genap tahun 2020 yang dilakukan melalui beberapa waktu. Populasi dalam penelitian ini adalah siswa tunagrahita ringan jenjang SMPLB. Sampel dalam penelitian ini adalah siswa tunagrahita ringan kelas IX-C

Pengambilan sampel dalam penelitian ini menggunakan teknik purposive sampling, yaitu teknik penentuan sampel dengan pertimbangan tertentu (Sugiyono, 2017). Peneliti mengambil sampel dengan beberapa pertimbangan yaitu (1) siswa kelas IX-C memiliki kemampuan dan nilai rata-rata menulis yang kurang, (2) peneliti mempertimbangkan keadaan atau suasana siswa dalam belajar. Berdasarkan pertimbangan tersebut, peneliti menentukan kelas IX-C sebagai sampel penelitian.

Dalam penelitian ini, peneliti melakukan pengumpulan data dengan melakukan beberapa cara yaitu observasi, tes, dan dokumentasi. Observasi dilakukan pada awal penelitian untuk memperoleh data mengenai kemampuan awal menulis cerita fantasi siswa tunagrahita ringan. Selain itu, observasi juga dilakukan saat siswa tengah menggunakan media gambar dalam pembelajaran menulis cerita fantasi. Tujuan observasi ini dilakukan untuk mengetahui proses pembelajaran dan akibat yang ditimbulkan setelah pembelajaran. Tes yang dilakukan merupakan tes unjuk kerja. Tes dilakukan untuk mengukur hasil yang dicapai siswa setelah diterapkannya media gambar pada pembelajaran menulis cerita fantasi.

Peneliti mengumpulkan data dengan menggunakan teknik dokumentasi yang meliputi dokumentasi berupa gambar pada saat proses pembelajaran dan dokumentasi hasil lembar kerja siswa. Penelitian ini menggunakan analisis data deskriptif kuantitatif. Analisis data dilakukan dengan menghitung, menjumlahkan dan mencari nilai rata-rata dari penilaian keseluruhan yang terdiri dari aspek struktur dan ciri kebahasaan cerita fantasi.

\section{Hasil Penelitian dan Pembahasan}

Secara umum, kemampuan menulis cerita fantasi siswa kelas IX-C dengan menggunakan media gambar berkategori sangat mampu dengan skor rata-rata 4 yang berada pada interval $4-5,00$ dan indeks penilaian 80,5 yang juga berpredikat baik.

Berdasarkan rumusan masalah yang dikemukakan pada bab 1, berikut dideskripsikan gambaran kemampuan menulis cerita fantasi siswa tunagrahita ringan dengan menggunakan media gambar. Adapun aspek penilainnya yaitu struktur yang terdiri dari orientasi, komplikasi, resolusi dan penggunaan bahasa yang terdiri dari penggunaan kata ganti, deskripsi latar, makna kias makna khusus, urutan waktu, ungkapan keterkejutan, dan kalimat langsung.

Tabel Kemampuan Menulis Cerita Fantasi dengan Menggunakan Media Gambar Siswa Tunagrahita ringan

\begin{tabular}{llccccc}
\hline \multirow{2}{*}{ Aspek yang Dinilai } & \multicolumn{3}{c}{ Kategori Kemampuan Ssiwa } \\
& & SM & M & CM & KM & TM \\
\hline \multirow{2}{*}{ Orientasi } & $83,8 \%$ & $12,9 \%$ & $3,2 \%$ & $0 \%$ & $0 \%$ \\
\cline { 2 - 6 } Struktur & Komplikasi & $80,6 \%$ & $16,1 \%$ & $3,2 \%$ & $0 \%$ & $0 \%$ \\
\hline
\end{tabular}




\begin{tabular}{|c|c|c|c|c|c|c|}
\hline & Resolusi & $67,7 \%$ & $25,8 \%$ & $6,4 \%$ & $0 \%$ & $0 \%$ \\
\hline \multirow{6}{*}{$\begin{array}{c}\text { Penggunaan } \\
\text { Bahasa }\end{array}$} & Penggunaan Kata Ganti & $83,8 \%$ & $16,1 \%$ & $0 \%$ & $0 \%$ & $0 \%$ \\
\hline & Deskripsi Latar & $87,0 \%$ & $9,6 \%$ & $3,22 \%$ & $0 \%$ & $0 \%$ \\
\hline & $\begin{array}{c}\text { Makna Kias dan Makna } \\
\text { Khusus }\end{array}$ & $32,2 \%$ & $48,3 \%$ & $16,1 \%$ & $3,22 \%$ & $0 \%$ \\
\hline & Penanda Urutan Waktu & $70,9 \%$ & $25,8 \%$ & $3,22 \%$ & $0 \%$ & $0 \%$ \\
\hline & Ungkapan Keterkejutan & $83,8 \%$ & $16,1 \%$ & $0 \%$ & $0 \%$ & $0 \%$ \\
\hline & Kalimat Langsung & $48,3 \%$ & $25,8 \%$ & $22,5 \%$ & $3,22 \%$ & $0 \%$ \\
\hline
\end{tabular}

Berpedoman pada hasil penelitian maka telah diketahui bagamaiana kemampuan menulis cerita fantasi dengan menggunakan media gambar siswa tunagrahita ringan. Pada materi ini, peneliti memilih menggunakan media gambar dengan tujuan untuk mempermudah siswa dalam mengembangkan imajinasinya atau memperjelas sajian ide sehingga mereka mudah menuangkan apa yang ada dipikirannya kedalam bentuk tulisan.

Aspek yang dinilai pada materi menulis cerita fantasi ini ada dua yaitu struktur dan penggunaan bahasa. Penilaian dari tiap aspek struktur dan penggunaan bahasa berpedoman pada indikator dengan deskriptor jika siswa sangat terampil dengan memenuhi tiga indikator menulis dengan sangat baik memperoleh skor 5, apabila siswa terampil menulis tiga indikator sangat terampil dan dua indikator cukup terampil memperoleh skor 4 , apabila siswa terampil menulis dua indikator cukup terampil dan satu indikator satu cukup terampil siswa memperoleh skor 3, apabila siswa terampil menulis dua indikator cukup terampil dan siswa sedikit menulis indikator kurang terampil siswa memperoleh skor 2, dan apabila siswa tidak terampil memenuhi ketiga indikator tersebut maka siswa memperoleh skor 1.

Hasil penelitian menunjukkan bahwa kemampuan menulis cerita fantasi dengan menggunakan media gambar siswa tunagrahita ringan berkategori sangat mampu. Hal ini dapat dilihat dari hasil pengolahan data pada aspek struktur dan penggunaan bahasa dengan persentase paling besar berada di kategori sangat mampu.

Penggunaan media gambar pada saat pembelajaran menulis cerita fantasi membuat siswa lebih bersemangat dalam proses belajar mengajar. Penulis membagi media gambar menjadi tiga tema yaitu kendaraan, kegiatan sehari-hari, dan benda. Alasan dipilihnya tema tersebut karena menyesuaikan dengan apa yang ada di kehidupan siswa sehari-hari, dengan maksud agar siswa menyadari bahwa imajinasi dapat timbul dengan hal-hal kecil yang ada di sekitar mereka.

Proses pembelajaran menulis cerita fantasi terasa lebih menyenangkan dengan menggunakan media gambar. Ketika seluruh siswa telah mendapatkan kartu gambarnya masing- masing, mereka langsung saling memamerkan ide dengan teman sebangkunya. Tulisan yang dihasilkan oleh siswa sangat memuaskan. Namun, dari seluruh aspek yang dinilai, masih ada beberapa siswa yang tergolong 
kurang terampil dalam menuliskan aspek tersebut, salah satunya pada aspek ciri kebahasaan.

\section{Kesimpulan}

Berdasarkan hasil penelitian dan pembahasan yang telah diuraikan pada hasil penelitian dan pembahasan, dapat disimpulkan bahwa proses pembelajaran menulis cerita fantasi terasa lebih menyenangkan dengan menggunakan media gambar. Hal ini karena media yang digunakan dalam cerita fantasi merupakan pengembangan dari teks narasi yang dijadikan sebuah cerita fiktif. Hasil penelitian menunjukkan dalam menulis cerita fantasi, siswa mengandalkan daya imajinasinya ketika membayangkan sesuatu yang tidak terjadi di kehidupan nyata. Selanjutnya penggunaan media gambar pada saat pembelajaran menulis cerita fantasi membuat siswa lebih bersemangat dalam proses belajar mengajar. Selain itu hasil menunjukkan bahwa kemampuan menulis cerita fantasi dengan menggunakan media gambar pada siswa tunagrahita ringan berkategori sangat mampu dengan skor rata-rata 4 yang berada pada interval 4 - 5,00 dan memperoleh indeks penilaian 80,6 yang terdapat pada interval penilaian $70-84$.

\section{Daftar Rujukan}

Arikunto, S. (2013). Prosedur Penulisan: Suatu Pendekatan Praktik. Jakarta: Rineka Cipta.

Arsyad, A. (2015). Media Pembelajaran. Jakarta: Raja Grafindo Persada.

Dalman. (2015). Keterampilan Menulis. Jakarta: Raja Grafindo Persada.

Fitri, Eka. (2017). Rancang Bangun Media Pembelajaran Untuk Anak Tunagrahita Berbasis Multimedia (Studi Kasus: SLB ABCD Kuncup Mas Banyumas).

Hamalik, O. (2010). Perencanaan Pengajaran Berdasarkan Pendekatan Sistem. Jakarta: Bumi Aksara.

Kurniawan, H. (2014). Pembelajaran Menulis Kreatif. Bandung: Remaja Rosdakarya.

Nurgiyantoro, B. (2015). Teori Pengkajian Fiksi. Yogyakarta: Gadjah Mada University Press.

Nurgiyantoro, B. (2015). Penilaian Otentik dalam Pembelajaran Bahasa. Yogyakarta: Gadjah Mada University Press.

Nurgiyantoro, B. Gunawan. Marzuki. (2012). Statistik Terapan Untuk Ilmu-Ilmu Sosial. Yogyakarta: Gadjah Mada University Press.

Rimawati, E. (2017). Ragam Media Pembelajaran. Yogyakarta: Dee Publishing.

Saddhono, K.S. (2014). Pembelajaran Keterampilan Berbahasa Indonesia Teori dan Aplikasi. Yogyakarta: Graha Ilmu.

Sadiman dkk. (2014). Media Pendidikan Pengertian, Pengembangan, dan Pemanfaatannya. Jakarta: Raja Grafindo Jakarta.

Sani, A.R. (2015). Inovasi Pembelajaran. Jakarta: Bumi Aksara.

Sugiyono. (2017). Metode Penelitian Pendidikan: Pendekatan Kuantitatif, Kualitatif, dan R\&D. Bandung: Alfabeta.

Sumantri, M.S. (2015). Strategi Pembelajaran (Teori dan Praktik di Tingkat Pendidikan Dasar). Jakarta: Rajawali Pers.

Tarigan, H.G. (2013). Menulis Sebagai Suatu Keterampilan Berbahasa. Bandung: Angkasa

Yosiani, Novita. (2014). Relasi Karakteristik Anak Tunagrahita Dengan Pola Tata Ruang Belajar di Sekolah Luar Biasa. E-Journal Graduate Unpar 1(2):111-24 